Louisiana State University

LSU Digital Commons

Faculty Publications

Department of Oceanography \& Coastal

Sciences

2006

Oxygen Depletion in the Gulf of Mexico Adjacent to the

Mississippi River

Nancy N. Rabalais

R. Eugene Turner

Follow this and additional works at: https://digitalcommons.Isu.edu/oceanography_coastal_pubs

Digitart of the Oceanography Commons

Commons

Network

Logo 


\title{
OXYGEN DEPLETION IN THE GULF OF MEXICO ADJACENT TO THE MISSISSIPPI RIVER
}

\author{
Nancy N. Rabalais ${ }^{1}$ and R. Eugene Turner ${ }^{2}$ \\ ${ }^{1}$ Louisiana Universities Marine Consortium, Chauvin, Louisiana 70344, USA \\ ${ }^{2}$ Coastal Ecology Institute, Louisiana State University, Baton Rouge, Louisiana 70803, USA
}

\begin{abstract}
The seasonal formation of a bottom water layer severely depleted in dissolved oxygen has become a perennial occurrence on the Louisiana continental shelf adjacent to the Mississippi River system. Dramatic changes have occurred in this coastal ecosystem in the last half of the $20^{\text {th }}$ century as the loads of dissolved inorganic nitrogen tripled. There are increases in primary production, shifts in phytoplankton community composition, changes in trophic interactions, and worsening severity of hypoxia. The hypoxic conditions (dissolved oxygen less than $2 \mathrm{mg} \mathrm{l}^{-1}$ ) cover up to $22,000 \mathrm{~km}^{2}$ of the seabed in mid-summer. Dissolved oxygen concentrations seldom decrease to anoxia, but are often below $1 \mathrm{mg}$ $1^{-1}$ and down to $0.5 \mathrm{mg} \mathrm{l}^{-1}$. The continental shelf of the northwestern Gulf of Mexico is representative of systems in which nutrient flux to the coastal ocean has resulted in eutrophication and subsequently hypoxia. The Mississippi River influenced continental shelf is similar to systems, such as deep basins and fjords, with regard to biogeochemical processes of oxic versus suboxic conditions in the water column and sediments. However, the suboxic conditions for the Gulf of Mexico are less persistent in time and space due to the dynamic nature of the open continental shelf system. Also, anoxia at the seabed is not as common or long lasting.
\end{abstract}

Keywords: continental shelf, Gulf of Mexico, Mississippi River, hypoxia, anoxia, eutrophication, nitrogen, phosphorus, silica

\section{INTRODUCTION}

Anoxic and suboxic conditions exist naturally in the world's oceans in fjords, deep basins, and oxygen minimum zones [19, 24]. Similar conditions frequently occur where upwelling systems associated with western boundary currents impinge on the continental shelf. Oxygen depletion in coastal waters not subject to upwelled nutrients results from eutrophication usually initiated and maintained by increased nutrient loads under stratified conditions. Not all coastal systems with elevated nutrient loads undergo eutrophication or develop hypoxia. The 
processes of increased phytoplankton biomass, carbon accumulation, and oxygen depletion are more likely to occur in systems with long water residence times and where the water column is stratified by salinity, temperature, or both. The amount of suspended sediment delivered to a coastal system also may influence whether enhanced production will result from the changing nutrient inputs.

Nutrient load increases result from increasing human populations and their activities - application of nitrogen and phosphorus fertilizers, planting of leguminous crops, atmospheric deposition of nutrients, and municipal and industrial wastewater $[1,50]$. The consequences can be desirable or undesirable, as perceived by humans. Increased nutrients stimulate increased primary production and increased secondary production, and often the yield of commercially important fisheries. The negative effects may include increased noxious or harmful algal blooms, diminished water clarity, shifts in trophic interactions that do not result in the diatom-zooplankton-fish food web, loss of essential habitat and oxygen depletion. Over the last half of the $20^{\text {th }}$ century, the impacts of eutrophication, including oxygen depletion, increased in frequency and severity and expanded geographically $[3,10,27]$. This trend will continue in the future with increasing nutrient loads [43].

The continental shelf of the northwestern Gulf of Mexico is representative of systems in which nutrient flux to the coastal ocean has resulted in eutrophication and subsequently hypoxia. One other shelf environment with a similar scenario of changing nutrient loads and worsening hypoxia is presented for the northwestern shelf of the Black Sea that receives discharges from the Danube, Dniepr, and Dniestr rivers (Zaitsev, present volume).

\section{DISTRIBUTION AND DYNAMICS OF HYPOXIA}

We define hypoxia as dissolved oxygen less than $2 \mathrm{mg} \mathrm{l}^{-1}$, or ppm, because bottom-dragging trawls usually do not capture any shrimp or demersal fish below this level [40]. (Dissolved oxygen of $2 \mathrm{mg} \mathrm{l}^{-1}$ equates to $1.4 \mathrm{ml} \mathrm{l}^{-1}$ or $63 \mu \mathrm{M}$, and approximates $20 \%$ oxygen saturation in the $25^{\circ} \mathrm{C}$ and $35 \mathrm{psu}$ bottom water of the hypoxic zone.) Sharks will modify their behavior to escape oxygen concentrations that fall below $3 \mathrm{mg} \mathrm{l}^{-1}$. When dissolved oxygen values are below $2 \mathrm{mg} \mathrm{l}^{-1}$, they are often less than $1 \mathrm{mg} \mathrm{l}^{-1}$, a level that is stressful or lethal to benthic macroinfauna.

The second largest zone of oxygen-depleted coastal waters in the world is found in the northern Gulf of Mexico on the Louisiana/Texas continental shelf, an area that is influenced by the freshwater discharge and nutrient load of the Mississippi River system [33] (Fig. 1). The mid-summer areal extent of hypoxic waters averaged $13,000 \mathrm{~km}^{2}$ over the period 1985-2004, with the largest size mapped in 2002 at $22,000 \mathrm{~km}^{2}$ (Fig. 2). The seasonal cycle of freshwater 


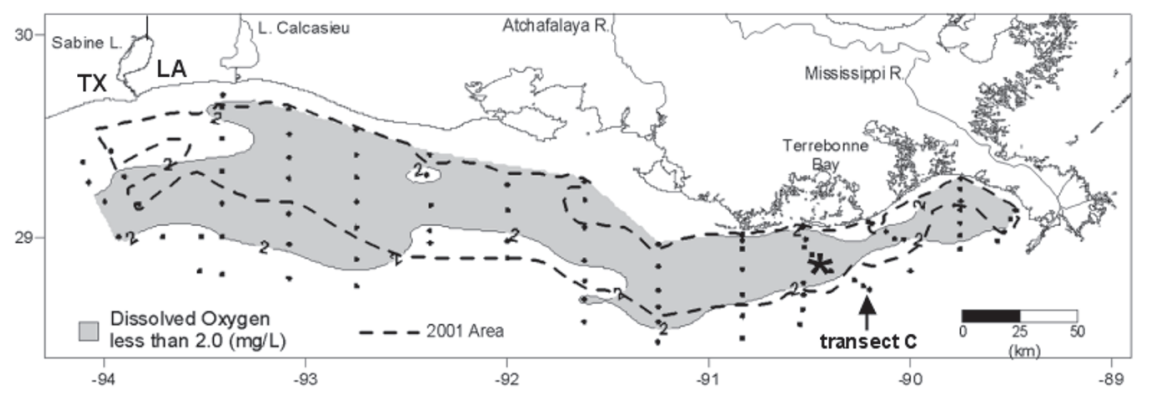

Figure 1. Distribution of bottom water hypoxia on the Louisiana/Texas coast in late July 2002 (stippled area) compared to July 2001 (area outlined by dashed line). Transect C and location of instrument mooring (*) identified. Data source: N.N. Rabalais, LUMCON.

discharge, nutrient flux, subtropical weather conditions, and circulation patterns that retain fresh water and associated constituents on the continental shelf controls the formation and maintenance of a spring-summer hypoxic zone. The seasonal formation of hypoxia is currently perennial, but hypoxia was not a dominant feature of the continental shelf prior to the major increase in nutrient loads beginning in 1960 .

\subsection{Physical Setting}

The Mississippi River forms the largest watershed on the North American continent. It discharges an average $580 \mathrm{~km}^{3}$ of fresh water per year to the northern Gulf of Mexico through two main distributaries - the main birdfoot delta southeast of the city of New Orleans, Louisiana and the Atchafalaya River delta $200 \mathrm{~km}$ to the west that carries about one-third of the flow [26]. The Mississippi and Atchafalaya rivers are the primary sources of fresh water, nitrogen and phosphorus to the northern Gulf of Mexico, delivering 80 percent of the freshwater inflow, 91 percent of the nitrogen load, and 88 percent of the phosphorus load [15]. Nutrient sources from atmospheric deposition, ground water and upwelled deeper Gulf water are estimated to be small or negligible $[17,36]$.

The fresh water, sediments, and dissolved and particulate materials are carried predominantly westward along the Louisiana/Texas inner to middle continental shelf, especially during peak spring discharge [36]. Although the area of the discharge's influence is an open continental shelf, the magnitude of flow, annual current regime and average 75-day residence time for fresh water result in an unbounded estuary stratified for much of the year. This stratification is 


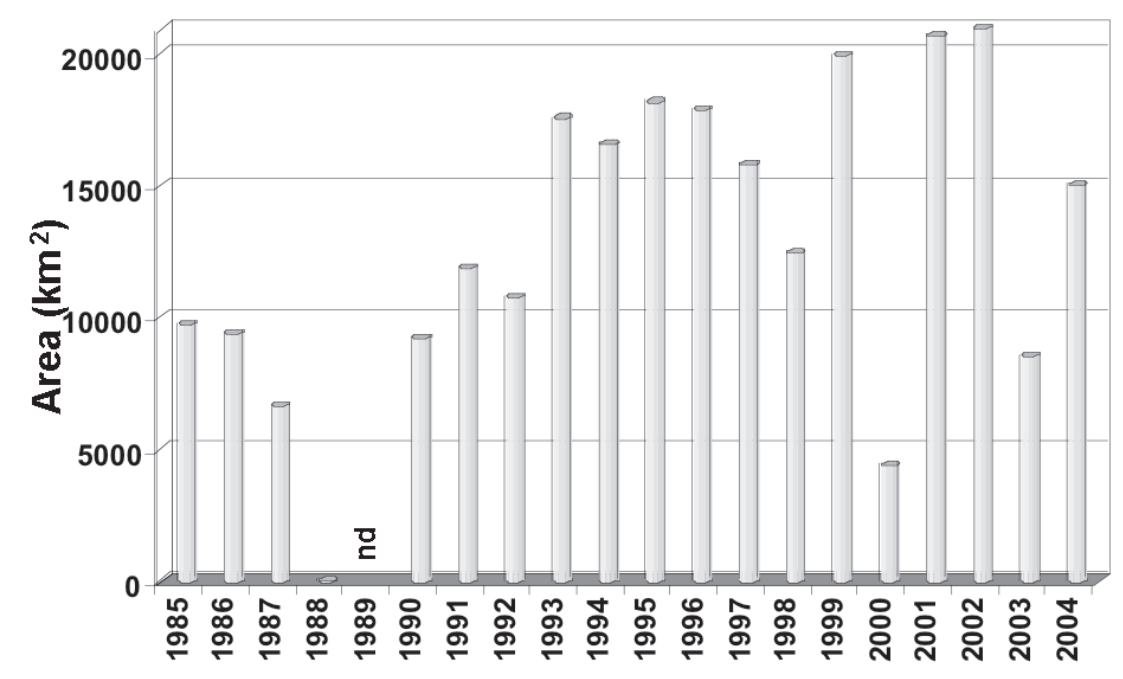

Figure 2. The areal extent of bottom water hypoxia in mid-summer on the Louisiana/Texas continental shelf from 1985-2004 (updated from [14]).

primarily due to salinity differences, and the stratification intensifies in summer with thermal warming of surface waters.

Mississippi River Watershed. The Mississippi River watershed drains 3.2 million $\mathrm{km}^{2}$ encompassing 41 percent of the lower 48 United States. The Mississippi River has been modified for navigation and flood control with narrowing of the channel and levees extending along the river from Cairo, Illinois to the Gulf of Mexico. Fifty-six percent of the wetlands in the Mississippi River basin have been lost to agriculture, navigation, reservoirs and leveeing. Land use in the watershed that supports 27 percent of the U.S.'s population (about 70 million people) is predominantly agriculture [17], the conversion of which began in the early 1800s as settlers migrated west across the North American continent [46]. Artificial subsurface drainage in much of the croplands expedites the transport of nitrate from the soil to surface waters. This management practice coupled with the increase in fertilizer applications can only increase the flux of nitrate from agricultural fields to the streams. In addition to landscape changes, anthropogenic inputs of nitrogen and phosphorus have increased from agriculture, point sources, and atmospheric deposition. 
The annual discharge of the Mississippi River system contributes sediment yields of $210 \times 10^{6} \mathrm{t}, 1.6 \times 10^{6} \mathrm{t}$ nitrogen, of which $0.95 \times 10^{6} \mathrm{t}$ is nitrate and $0.58 \times 10^{6} \mathrm{t}$ is organic nitrogen, $0.1 \times 10^{6} \mathrm{t}$ phosphorus and $2.1 \times 10^{6} \mathrm{t}$ silica [17]. The estimate of current river nitrogen export from the Mississippi River watershed over 'pristine' river (pre-agricultural and pre-industrial condition) nitrogen export is a 2.5- to 7.4-fold increase [20]. The average concentration and flux of nitrogen (per unit volume discharge) increased from the 1950 s to 1980s, especially in the spring; this is consistent with increased use of fertilizer in the watershed [47].

Changes in River Constituents and Ecosystem Response. Changes in the coastal ecosystem are directly linked to the changes within the watershed and nutrient loading to the continental shelf, especially of nitrate, which tripled in the last half of the 20th century [36, 37, 46, 48]. Evidence from long-term data sets and the sedimentary record demonstrate that indices of increased marine productivity and subsequent worsening of oxygen stress are highly correlated with historic increases in riverine dissolved inorganic nitrogen concentrations and loads over the last 50 years [37] and implied nutrient load changes over the last 200 years [46]. Evidence comes in long-term changes in Secchi disk depth and diatom productivity, increased accumulation of diatom remains and marineorigin carbon in sediments, and indicators of worsening oxygen conditions in the sediments-glauconite abundance, benthic foraminiferan diversity and community composition, and ostracod diversity. The sediment data suggest that hypoxia was not a feature of the continental shelf before 1900 and that hypoxia may have existed at some level before the 1940-1950 time period, but that it has worsened since then. Recent models of how the size and intensity of hypoxia are related to nitrate flux from the Mississippi River [22, 42, 49] indicate that hypoxia as a widespread phenomenon was not likely on the Louisiana shelf before the early 1970s. Thus, the continental shelf hypoxia/anoxia adjacent to the Mississippi River results from anthropogenic activity within the watershed and subsequent eutrophication and oxygen deficiency in a physical setting conducive to the formation of hypoxia.

Because both the amount of fresh water delivered (an influence on stratification) and nitrogen loading (an influence on primary production) influence the distribution and dynamics of hypoxia, it is important to understand the interannual variability in discharge as it affects seasonal biological processes. Using two different approaches, Donner et al. [11] and Justić et al. [23] agreed that only 20 to 25 percent of the increased nitrate flux between the mid-1960s to the mid-1990s was attributable to greater runoff and river discharge, with the rest due to increased nitrogen loading from the landscape. With nitrate concentrations in the lower Mississippi River remaining near $100 \mu \mathrm{M}$ since 
the early 1990s [45], climate-driven changes in discharge now influence the seasonal formation of hypoxia more than they did before 1990 .

Physical and Biological Processes. The relative influence of the physical features of the system and the progression of biological processes vary spatially and over an annual cycle and are directly linked with the dynamics of the Mississippi and Atchafalaya discharges.

The physical structure of the water column is defined by water masses that differ in temperature, salinity, or both. Fresh water from the rivers and seasonally-warmed surface waters reside above the saltier, cooler and more dense water masses near the bottom. The existence of a strong near-surface pycnocline, usually controlled by salinity differences, is a necessary condition for the occurrence of hypoxia, while a weaker, seasonal thermocline often guides the morphology of the bottom water hypoxia [51] (Fig. 3). Stratification goes through a well-defined seasonal cycle that is generally strongest during summer and weakest during winter [33]. These changes are responsive to the strength and phasing of river discharge, the changing frequency of cold front passages, regional circulation and air-sea heat exchange processes.
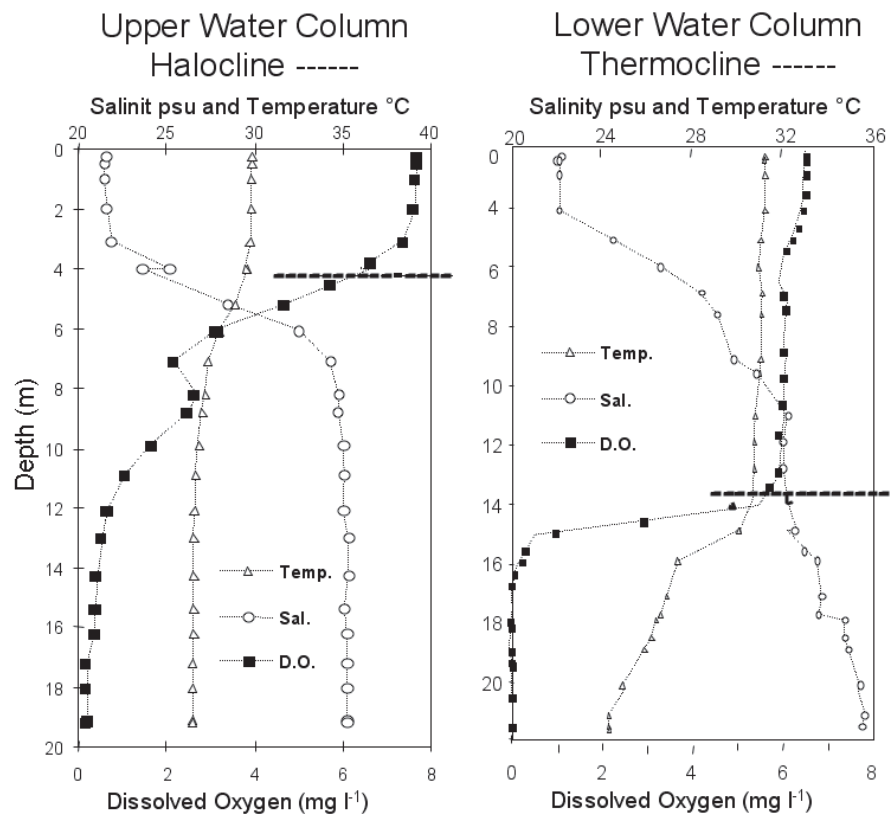

Figure 3. Left panel: example of upper water column halocline and oxycline. Right panel: example of upper water column halocline and lower water column thermocline and oxycline. Data source: N.N. Rabalais, LUMCON. 
The concentrations and total loads of nitrogen, phosphorus and silica delivered to the coastal ocean influence the productivity of the phytoplankton community, the types of phytoplankton that are most likely to grow and the flux of phytoplankton-derived organic matter [12, 36, 45]. Phytoplankton not incorporated into the food web and fecal material generated via the food web sink into bottom waters where they are decomposed by aerobic bacteria. The source of the organic matter for this respiratory activity is mostly from marine phytoplankton growth stimulated by riverine-delivered nutrients, and not from the carbon in the Mississippi River [16]. The bacterial respiration in the lower water column and seabed results in a decline in oxygen concentration when oxygen is depleted faster than it can be replaced by vertical diffusion through the stratified water column.

\subsection{Variability of Gulf of Mexico Hypoxia}

The distribution of hypoxia on the Louisiana/Texas continental shelf reflects the interaction of physical and biological processes dominated by riverine inputs. Decreases in nutrient concentrations away from the Mississippi and Atchafalaya rivers are paralleled by decreases in surface water chlorophyll (Fig. 4) [34, 35]. Gradients away from the rivers result from mixing of the buoyant plumes and biological uptake and regeneration of nutrients. Dissolved inorganic nitrogen (DIN, nitrate+nitrite+ammonium) is high near the Mississippi River delta and composed primarily of nitrate. Down current from the delta, ammonium is the dominant DIN form and in sufficient supply to support primary production. Phosphate is uniformly present, and silicate concentrations are high near the delta and remain sufficient for diatom growth across a large area. There is an optimal distance and depth for the formation of hypoxia based on strength of the stratification, light conditions, nutrient availability and rates of primary production and flux of organic matter to the seabed. This is qualitatively illustrated in the compilation of 17 mid-summer surveys (1985-2002, Fig. 5) that shows the frequency of hypoxia is highest down current (west) from the freshwater and nutrient discharges from the Mississippi and Atchafalaya rivers. Empirical models strongly correlate the size of the mid-summer hypoxic area with the riverine nitrate load over several months prior to the mapping cruise $[42,49]$.

Spatial Extent. The hypoxic water mass is distributed across the Louisiana shelf west of the Mississippi River and onto the upper Texas coast (mapped in mid- to late July) [37]. Hypoxia extends from near shore to as much as 125 $\mathrm{km}$ offshore and in water depths up to $60 \mathrm{~m}$. The size averaged $13,000 \mathrm{~km}^{2}$ over the period 1985-2004, with a range from negligible in 1988 (a summer drought year for the Mississippi River basin) up to $22,000 \mathrm{~km}^{2}$ (Fig. 2). Hypoxia may form in two distinct areas west of the Mississippi and Atchafalaya River 

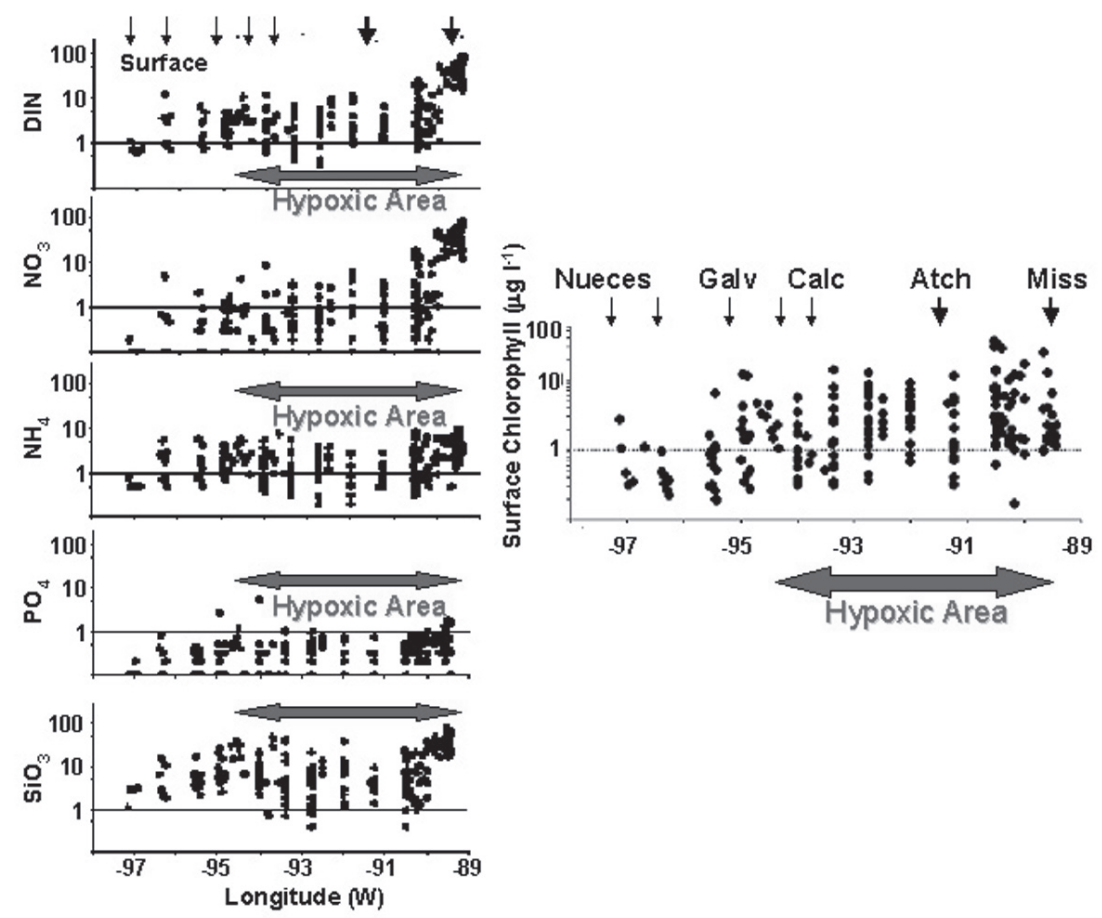

Figure 4. Concentration of surface water nutrients $(\mu \mathrm{M})$ and chlorophyll biomass $\left(\mu \mathrm{g}^{-1}\right)$ on the Louisiana/Texas shelf for multiple seasons in 1985-2002 (modified from [40]). The black arrows indicate the large inputs of fresh water and nutrients from the Mississippi and Atchafalaya Rivers, and minor contributions from the Calcasieu, Galveston, Nueces and other estuaries. The shaded horizontal arrows indicate the typical distance alongshore for the mid-summer hypoxic zone.

deltas (Fig. 6). The water between these two areas, however, is also depleted in oxygen (less than $3 \mathrm{mg} \mathrm{l}^{-1}$ ). Hypoxia more often forms a single continuous zone (examples for 2001 and 2002 in Fig. 1). The 1998 hypoxic zone was atypically concentrated in deeper water than usual on the eastern Louisiana shelf. Although the bottom extent of hypoxia in 1998 was less than 1997 (Fig. 2), the volume of the hypoxic water mass in 1998 was greater than in 1997 [35]. The smaller area in 2003 resulted from a series of tropical storms that moved through the area two weeks prior to the mapping cruise and disrupted the stratification.

Most instances of hypoxia elsewhere in the northern Gulf of Mexico along the shelf farther to the west and also east of the Mississippi River delta are infrequent, short-lived, and limited in extent [30, 37]. Hypoxia on the upper Texas coast is usually an extension of the hypoxic zone off Louisiana $[18,28]$. Hypoxia east of the Mississippi River is also isolated and ephemeral, but occurs 


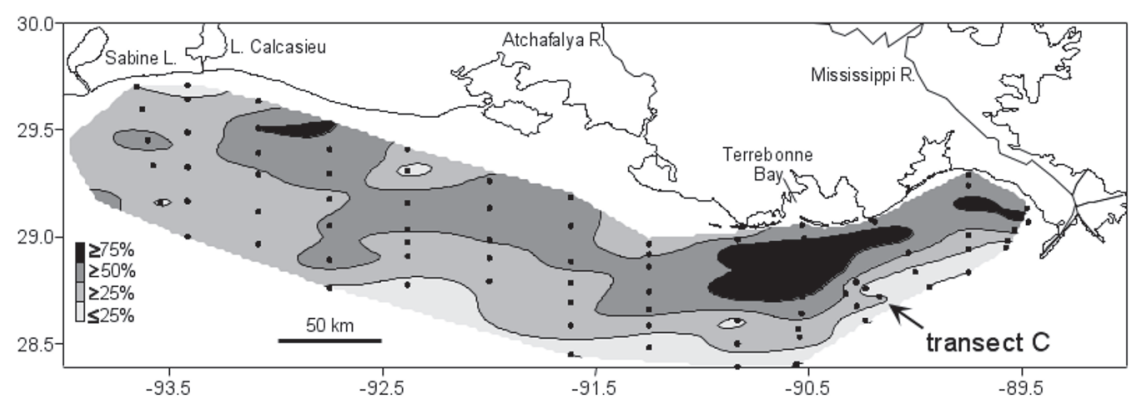

Figure 5. Distribution of frequency of bottom water hypoxia in mid-summer on the Louisiana/Texas shelf for 1985-2002 (modified from [14]).

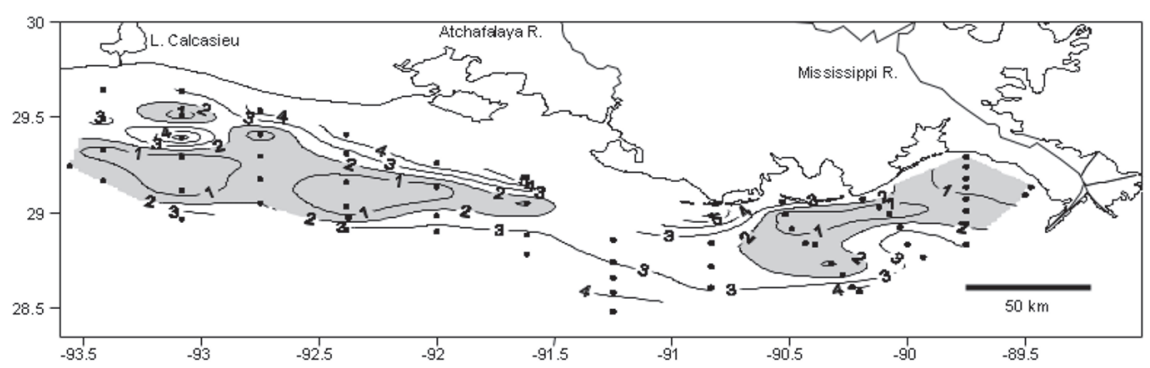

Figure 6. Isopleths of bottom water dissolved oxygen concentrations ( $\mathrm{mg}^{-1}$ for 7-17 July 1986 with values less than $2 \mathrm{mg} \mathrm{l}^{-1}$ stippled. Note the extent of values less than $3 \mathrm{mg} \mathrm{l}^{-1}$, a level below which some nekton are excluded. Data source: N.N. Rabalais, LUMCON.

more frequently during flood stages of the Mississippi River when summer currents move more water to the east of the birdfoot delta. From limited data where both sides of the delta were surveyed ( [44], National Marine Fisheries Service unpubl. data), there is no evidence that the area of low oxygen forms a continuous band around the delta.

Seasonal Variability. The broad spatial coverage of hypoxia has been routinely measured only once per year in mid-summer, and the spatial extent over the whole shelf during other parts of the year is less well known. More frequent sampling along a transect $\mathrm{C}$ on the southeastern Louisiana coast (labeled in Fig. 1 and 5) indicates that critically low dissolved oxygen concentrations occur from as early as late February through early October and nearly continuously from mid-May through mid-September [37]. Data from trawl surveys in the Mississippi River bight indicate that hypoxia occurs in that area in 
6- to 10-m water depth as late as November (T. Romaire pers. comm.). Hypoxia is rare in late fall and winter. The monthly average value of bottom oxygen concentration along transect $\mathrm{C}$ illustrates the seasonal progression of worsening hypoxia across an increasingly greater area in May through August (Fig. 7). The persistence of extensive and severe hypoxia into September and October depends on the timing of the breakdown of vertical stratification from either tropical storms, passage of cold fronts or thermal turnover of the water column.

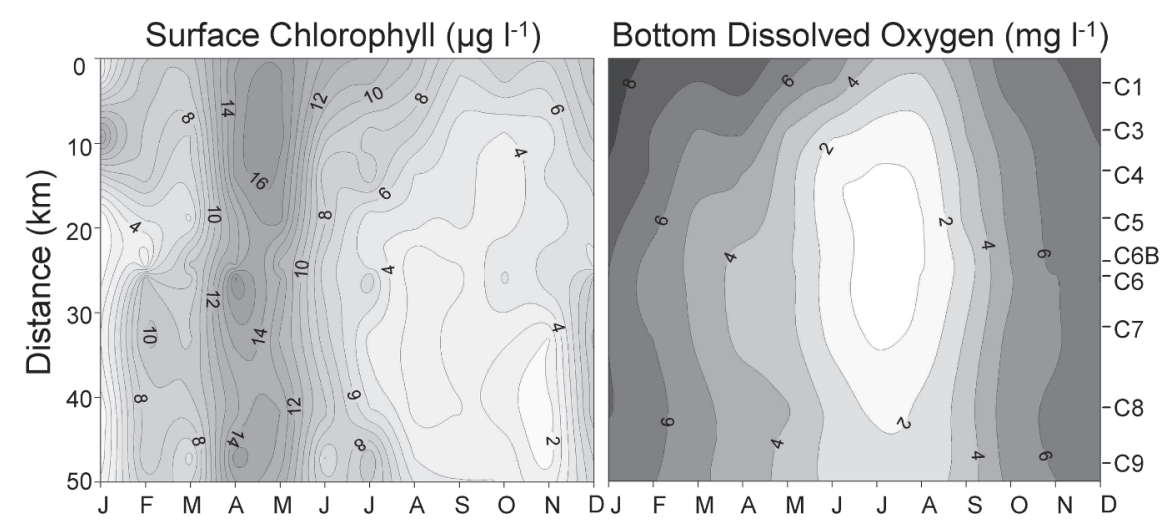

Figure 7. Long-term average (1985-1997) of surface water chlorophyll and bottom water dissolved oxygen by month for nine stations located 3 to $47 \mathrm{~km}$ from shore in water depths of 5 to 30 m. Data source: N.N. Rabalais, LUMCON.

Once hypoxia becomes established in mid-summer, much of the onshoreoffshore variability in distribution can be attributed to wind-induced cross-shelf advection or tidal advection $[38,39]$. The low oxygen water mass is displaced into deeper water following winds that produce downwelling-favorable conditions. Upwelling-favorable conditions push the hypoxic water mass closer to the barrier island shore.

Vertical Distribution. Hypoxia is sometimes found in a thin lens overlying the seabed, but more often occurs well up into the water column depending on the location of the pycnocline(s) (Fig. 3). Hypoxia may encompass from 10 to over 80 percent of the total water column, but is normally only 20 to 50 percent of the water column. At the high end of this range, hypoxic waters may reach to within $2 \mathrm{~m}$ of the surface in a 10-m water column, or to within $6 \mathrm{~m}$ of the surface in a 20-m water column.

Mid-water oxygen minima often occur below concentrations of phytoplankton at a density discontinuity in the upper or mid-water column. Where surface phytoplankton biomass is high, the sinking cells and fecal pellets 
from zooplankton grazing settle through the water column and concentrate in fine layers at pycnoclines. Respiration in these interfaces often exceeds oxygen production via photosynthesis so that oxygen depleted layers form at or immediately below the concentration of organic matter. Examples are provided from within areas of hypoxia in July 2004 following a period of unseasonably high discharge of the Mississippi River (Fig. 8). Mid water oxygen minima, however, are not limited to areas of oxygen-depleted bottom water. These features are common near the Mississippi River plume in spring and diminish in frequency and strength with distance from the discharge.

High Frequency Oxygen Measurements. Continuously recording (15-min interval) oxygen meters have been deployed near the bottom at a 20-m station on transect $C$ since 1990 . There is variability within the year and between years, but the pattern (Fig. 9) that usually develops at this location includes: (i) gradual declines of bottom oxygen concentrations through respiration and more rapid reoxygenation from mixing events, (ii) persistent hypoxia and often anoxia for extended periods in May-September, (iii) isolated intrusions of higher oxygen content water from depth during upwelling-favorable wind conditions followed by a movement of the low oxygen water mass back offshore, and (iv) tropical storms, hurricanes or cold fronts in the late summer and fall that mix the water column sufficiently to prevent prolonged instances of low oxygen concentrations [33].

Another recording oxygen meter was deployed in a similar depth of 20-m but $77 \mathrm{~km}$ to the east and closer to the Mississippi River delta where the depth gradient of the shelf is much steeper [39]. At that station hypoxia occurred for only 44 percent of the record from mid-June through mid-October (compared to 75 percent at the station on transect C). There was a strong diurnal pattern in the oxygen time-series for the former and not for the latter. The dominant coherence of the diurnal peaks of oxygen concentration from the site in the Mississippi River bight with bottom pressure records suggests that the dissolved oxygen signal was due principally to advection of the interface between hypoxic and normoxic water by tidal currents.

\section{BIOGEOCHEMICAL PROCESSES IN HYPOXIA}

Most of the biogeochemical investigations of the highly productive plume of the Mississippi River have focused on surface waters with regard to bacterial production, respiration, carbon remineralization, and nutrient uptake and regeneration, and less often with similar processes in sediments overlain by hypoxic waters. Little is known about nutrient and carbon transformations within the mid-water hypoxic layers. The biogeochemical processes of oxic versus hypoxic conditions and oxic/anoxic interfaces in the water column and sediments 

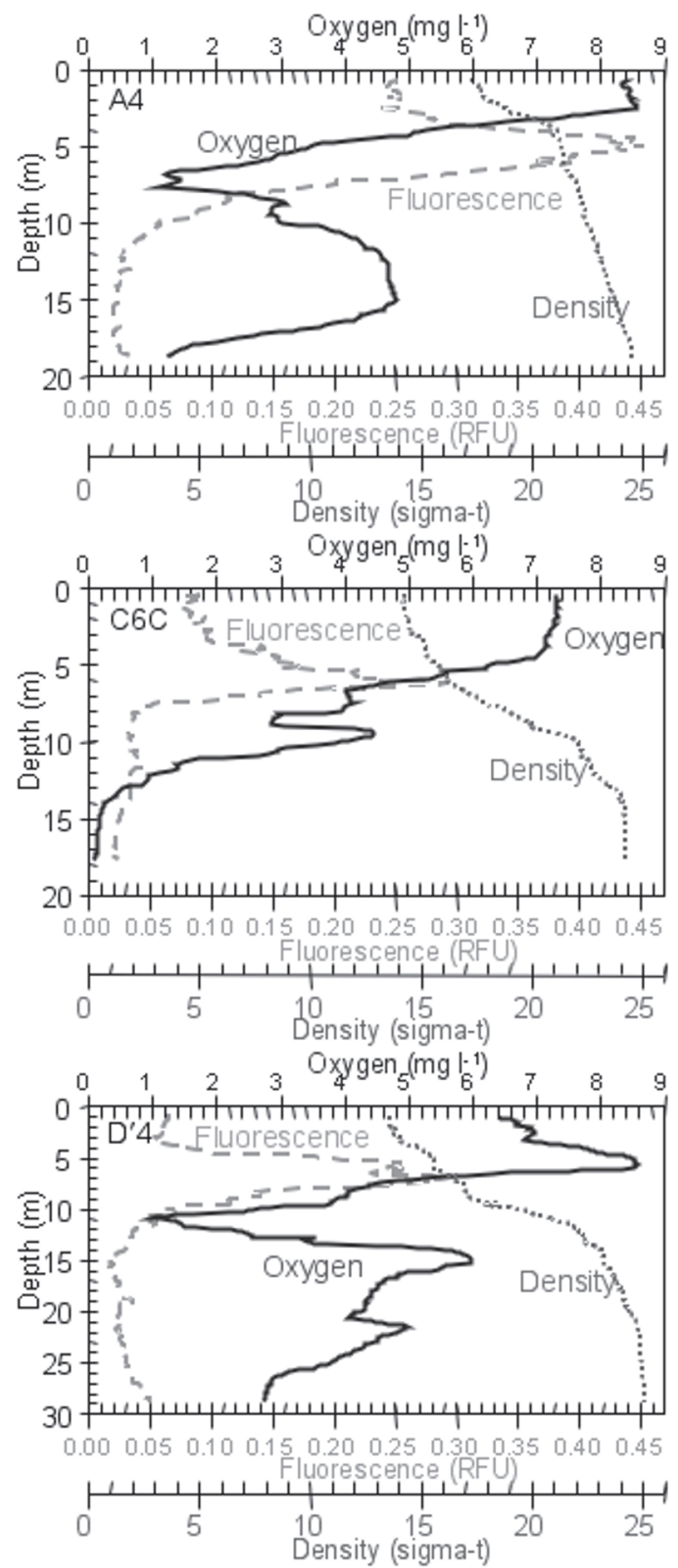

Figure 8. Examples of mid-water oxygen minima in areas of hypoxic bottom waters, July 2004. Oxygen, solid line; fluorescence, dashed line; density, dotted line. Station A4 is $37 \mathrm{~km}$ northwest of Southwest Pass of the Mississippi River, 20-m depth, 0035 GMT, sunrise; station C6C is $100 \mathrm{~km}$ west of Southwest Pass and $100 \mathrm{~km}$ east of the Atchafalaya River, 18-m depth, 1610 GMT, mid-morning; station D'4 is $120 \mathrm{~km}$ from Southwest Pass and $110 \mathrm{~km}$ from the Atchafalaya River, 30-m depth, 0555 GMT, midnight. Data are from a SeaBird system with SBE43 oxygen probe calibrated by Winkler titrations, derived density, and fluorescence from a Turner SCUFA. Data from: N.N. Rabalais, LUMCON. 


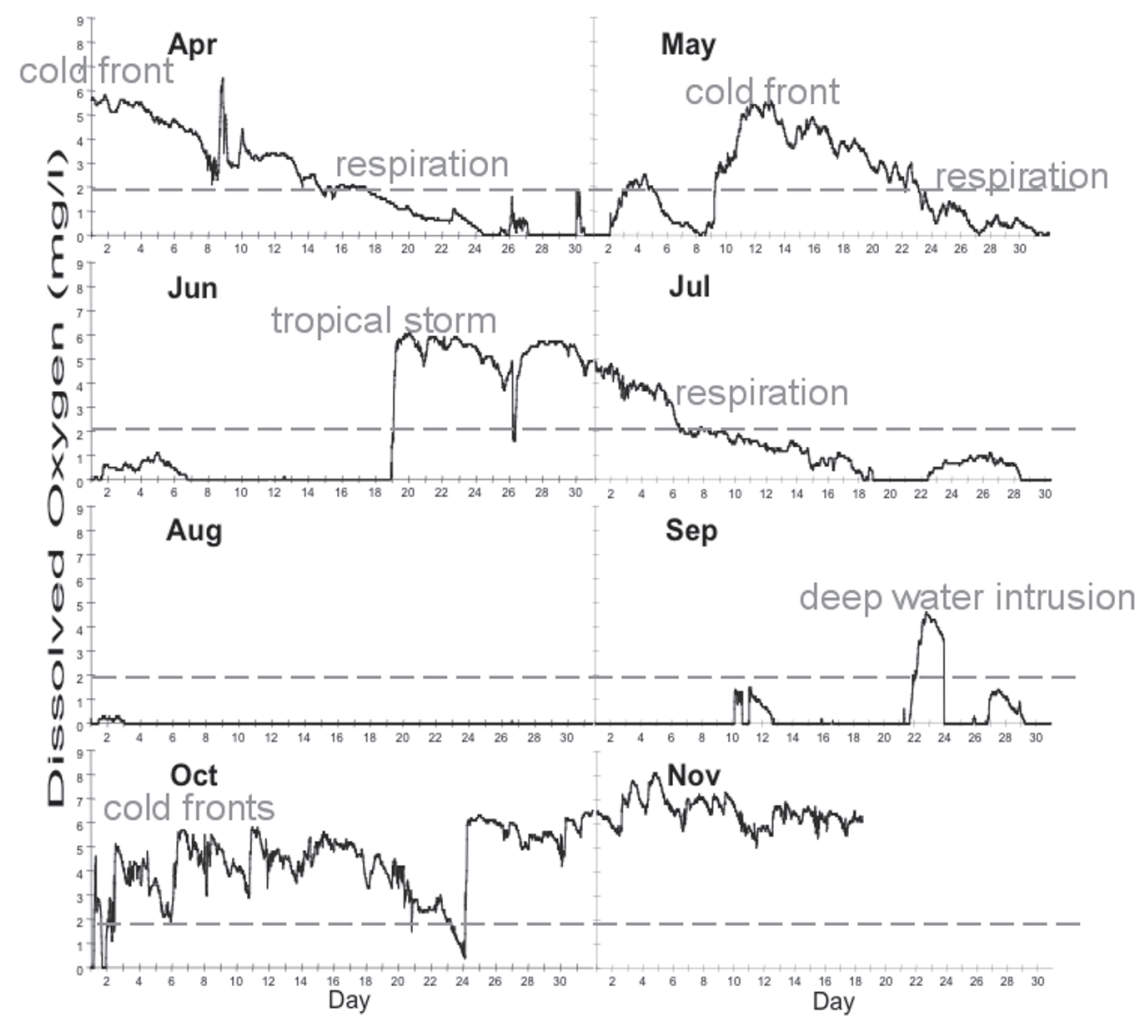

Figure 9. Continuous bottom water dissolved oxygen in 20-m depth on the continental shelf west of the Mississippi River (April-November 1993) (mooring site in Fig. 1). The horizontal dashed line defines hypoxia. Data source: N.N. Rabalais, LUMCON.

of Louisiana shelf are similar to other areas of the world ocean. However, the suboxic conditions for the northern Gulf of Mexico are less persistent in time and space due to the dynamic nature of the open continental shelf system. Also, anoxia at the seabed is not as common or long lasting.

\subsection{Hydrogen Sulfide}

The occurrence of anoxia and production of $\mathrm{H}_{2} \mathrm{~S}$ in bottom waters on this shelf are limited even though the continental shelf is seasonally hypoxic over a large area and oxygen concentrations are often below $0.5 \mathrm{mg} \mathrm{l}^{-1}$. While instrumentation may limit accuracy at levels below $0.1 \mathrm{mg} \mathrm{l}^{-1}$, the presence of $\mathrm{H}_{2} \mathrm{~S}$ in bottom waters is a definitive indicator that the dissolved oxygen concentration is $0.0 \mathrm{mg} \mathrm{l}^{-1}$. $\mathrm{H}_{2} \mathrm{~S}$ concentrations up to $50 \mu \mathrm{M}$ have been measured in bottom water samples that emitted a strong odor of $\mathrm{H}_{2} \mathrm{~S}$ (N.N. Rabalais et al. unpubl. 
data). $\mathrm{H}_{2} \mathrm{~S}$ concentrations of 2-5 $\mu \mathrm{M}$ were chemically detected, when there was still a faint $\mathrm{H}_{2} \mathrm{~S}$ odor. Thus, the 'odor indicator' has been used to determine the occurrence of anoxia. In a mid-summer survey of 80-90 stations, there are at most 10 stations in which the bottom water collections smelled of $\mathrm{H}_{2} \mathrm{~S}$ (N.N. Rabalais et al. unpubl. data). For the nine-station transect $\mathrm{C}$, up to two stations per month in June through September can have the $\mathrm{H}_{2} \mathrm{~S}$ smell. The presence of sulfur-oxidizing bacteria at the sediment-water interface on many occasions, observed both by divers and video surveillance from remotely operated vehicles [31], indicates that extremely low oxygen concentrations, though not anoxic, commonly allow for the presence of these bacteria on the sediment surface.

\subsection{Respiration and Oxygen Production}

The Louisiana shelf hypoxic area, as represented by a 20-m station (mooring site, transect C, Fig. 1), is predominantly heterotrophic throughout the year [21]. The difference between bottom water oxygen deficit (measured oxygen content below the oxygen content at $100 \%$ saturation) and surface water oxygen surplus (measured oxygen content above the oxygen content at 100\% saturation) is greatest in April-September.

Light conditions partially influence where hypoxic water masses are located and their severity. Extinction coefficients may be sufficiently improved at the edge of the hypoxia water mass to support benthic oxygen production. The Bierman et al. [2] model indicated that deeper light penetration might be more important with regard to hypoxia distribution in the western portion of the Louisiana shelf compared to the eastern area where the water clarity is lower (either due to suspended sediments or shading from high algal biomass). With sufficient light, photosynthesis at or near the sediment-water interface will occur and offset oxygen uptake processes to the point that anoxia does not frequently occur. The low oxygen concentration observed in respiration experiments (average $3.4 \mathrm{mg} \mathrm{l}^{-1}, n=40$ ), however, suggests that benthic oxygen production was relatively low [13].

The oxygen consumption rates in near-bottom waters were measured during several spring and summer cruises of multiple years [34, 44, 45]. Rates varied between 0.0008 to $0.29 \mathrm{mg} \mathrm{O}_{2} \mathrm{I}^{-1} \mathrm{hr}^{-1}$, and were sufficient to reduce the in situ oxygen concentration to zero in less than four weeks. The rates were inversely related to depth and decreased westward of the Mississippi River delta, consistent with the decrease in nutrients and chlorophyll $a$ concentrations in surface waters. Respiration rates per unit chlorophyll $a$ were highest in the spring, in shallower waters, and also closest to the Mississippi River delta. These results (1) indicate a strong vertical, rather than horizontal, coupling between oxygen consumption in bottom waters and organic loading from surface waters, and (2) are consistent with the hypothesis that the higher water column respiration 
rates are driven by river-derived nutrients stimulating in situ organic production that sinks to the bottom layers.

Respiration in sediments is an additional oxygen sink for these waters. Dortch et al. [13] suggested that this oxygen sink may sometimes equal respiration in the overlying waters, but most results (field and modeling experiments) indicate that the sediment consumption is seldom more than one-third of the total oxygen uptake below the pycnocline. Current work by Z. Quiñones et al. (pers. comm.) with oxygen isotopes will better define these processes.

\subsection{Low Redox Conditions}

In general, the relationships between bottom water oxygen concentration and the concentration of dissolved inorganic nitrogen forms, phosphate and silicate are inverse (Fig. 10).
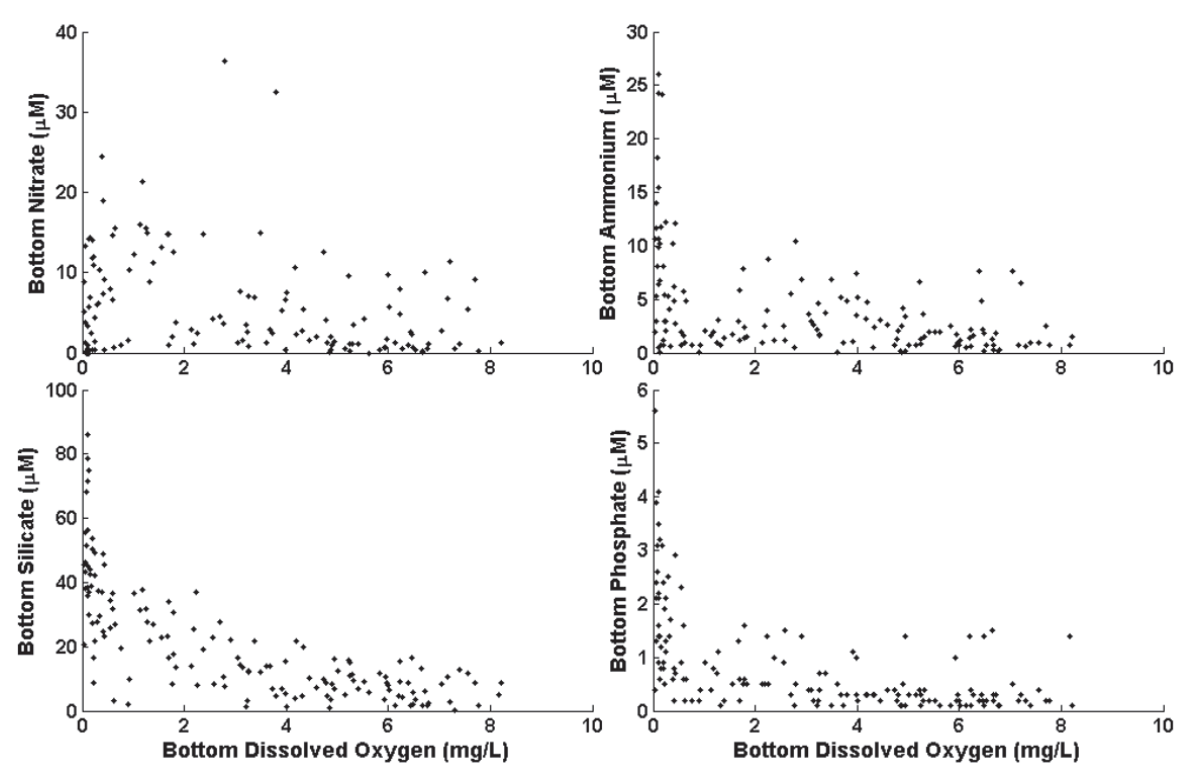

Figure 10. Comparisons of bottom water dissolved oxygen concentration and bottom water dissolved inorganic nutrient concentrations for a series of stations in $20 \mathrm{~m}$ depth on transect C within $1 \mathrm{~km}$ of each other between 1985-2002 for all months. Data source: N.N. Rabalais, LUMCON.

Most of the inorganic nitrogen is present as nitrate, but there are sometimes significant amounts of ammonium. Denitrification rates in sediments from stations within the hypoxic zone ranged between 150 and $410 \mu \mathrm{mol} \mathrm{N} \mathrm{m} \mathrm{hr}^{-1}$ $[8,7]$. The highest rates were observed when bottom water oxygen concentrations were between 1 and $3 \mathrm{mg}^{-1}$. Denitrification activity was significantly lower at stations where dissolved oxygen was lower than $1 \mathrm{mg} \mathrm{l}^{-1}$ or greater 
than $3 \mathrm{mg} \mathrm{l}^{-1}$. Associated nutrient data indicated that the dominant form of nitrogen shifts from nitrate to ammonium as anoxia is approached (as in Fig. 10). The lower denitrification rates where oxygen was less than $1 \mathrm{mg} \mathrm{l}^{-1}$ may be due to nitrate limitation or an increase in the competitive advantage of microorganisms capable of dissimilatory nitrate reduction to ammonium. Suppression of denitrification at low oxygen concentrations will increase the residence time of bioavailable nitrogen and could act as a positive feedback mechanism in the formation of hypoxic bottom waters.

Limited data from benthic flux chambers deployed in hypoxic waters in Louisiana indicated a net flux of dissolved inorganic nitrogen into the sediments as a result of consumption of nitrate and nitrite $\left(-1.2 \mathrm{mmol}\left(\mathrm{NO}_{3}^{-}+\mathrm{NO}_{2}^{-}\right) \mathrm{m}^{-2}\right.$ $\left.\mathrm{d}^{-1}\right)$ and an efflux of ammonium $\left(2.5 \mathrm{mmol} \mathrm{NH}_{4}{ }^{+} \mathrm{m}^{-2} \mathrm{~d}^{-1}\right)$ [41]. The overall net efflux of DIN was higher in waters with dissolved oxygen concentrations greater than $2 \mathrm{mg} \mathrm{l}^{-1}$ but still below saturation.

Preliminary measurements of nitrous oxide in a range of dissolved oxygen concentrations in the hypoxic area of the Louisiana shelf indicate that it is produced in low oxygen waters (M.B. Westley et al. unpubl. data). $\mathrm{N}_{2} \mathrm{O}$ was sometimes present in waters at $5 \mu \mathrm{M} \mathrm{O}_{2}$ or less, and its concentration was sometimes as high as two to three times higher than saturation levels. The concentration of $\mathrm{N}_{2} \mathrm{O}$ increased with depth through a 20-m water column as dissolved oxygen declined with depth. On the other hand, Childs et al. [7] found no nitrous oxide production in any of their experimental overlying water.

Higher phosphate and silicate concentrations at the lower dissolved oxygen levels are consistent with strong fluxes from the sediments as they become anoxic or near anoxic. Higher dissolved silicate fluxes from the sediments under hypoxic bottom waters in Chesapeake Bay were related to the flux of organic matter from surface waters, but only one month after deposition events (shown as elevated sediment chlorophyll $a$ concentrations) [4]. One expects then that the stations with higher silicate concentrations in bottom waters (Fig. 10) received a greater flux of silicate-based organic material in prior months.

Reduced forms of metals are often released from sediments during severe hypoxia. Mallini [25] found that dissolved Mn concentrations rapidly increased as oxygen concentrations fell below $63 \mu \mathrm{M}$. Extremely high dissolved $\mathrm{Mn}$ concentrations (1000 to $3200 \mu \mathrm{M}$ ) occurred in oxygen concentrations from 10 $\mu \mathrm{M}$ to anoxia.

The regeneration of nutrients in the lower water column or from the sediments could contribute to further nutrient-enhanced production in the upper mixed layer, if they diffuse or mix in significant amounts across the strong pycnocline present much of the year. The rates of these processes, if they occur, are not known, nor have they been estimated. Preliminary examination of vertical nutrient profiles does not indicate a transfer of high nutrients in hypoxic bottom waters into the overlying water column on the Louisiana shelf (N.N. Rabalais 
et al. unpubl. data). Wind-induced mixing turned over the water column and introduced higher nutrients from the bottom into surface waters in shallow nearshore Louisiana shelf waters for a temporary enhancement of production [9]. The significance of bottom nutrient introduction to surface waters following mixing events in the hypoxic zone is not known.

\section{CONSEQUENCES TO LIVING RESOURCES}

Hypoxia is one manifestation of a suite of symptoms that may result from eutrophication. The effects of eutrophication, including hypoxia, are well known for some systems and include the loss of commercially important fisheries (e.g., Baltic and Black seas). The impacts of increased nutrient inputs and worsening hypoxia on overall system productivity are not well known for the Louisiana continental shelf food web. The hypoxic waters fall within an important commercial and recreational fishery zone that accounts for 25 to 30 percent of the annual coastal fisheries landings for the United States. The ability of organisms to reside, or even survive, either at the bottom or within the water column is affected as the depletion of oxygen progresses towards anoxia [31, 32]. When oxygen levels fall below critical values, those organisms capable of swimming (e.g., demersal fish, portunid crabs and shrimp) evacuate the area. Less motile fauna experience stress or die as oxygen concentrations fall to zero. Larger, longer-lived burrowing infauna are replaced by short-lived, smaller surface deposit-feeding polychaetes, and several taxa are absent from the fauna, for example, pericaridean crustaceans, bivalves, gastropods, and ophiuroids. These changes in benthic communities result in an impoverished diet for bottomfeeding fish and crustaceans and contribute, along with low dissolved oxygen, to altered sediment structure and sediment biogeochemical cycles.

Caddy [5] suggested that the fishery yield increases as nutrient loading increases, but, as the ecosystem becomes increasingly eutrophied, there is a drop in fishery yield. The benthos are the first resources to be reduced by increasing frequency of seasonal hypoxia and eventually anoxia; bottom-feeding fishes and crustaceans then decline. There is a negative relationship between the catch of brown shrimp (the largest economic fishery in the northern Gulf of Mexico) and the size of the mid-summer hypoxic zone [52]. The decadal average catch per unit effort of brown shrimp declined during the last forty years in which hypoxia was known to expand [14]. There are, however, changes in climate, river discharge, salinity of the estuary during critical development periods, acreage of nursery habitat and fishing effort that may also affect catch.

The point on the continuum of increasing nutrients versus fishery yields remains vague as to where benefits are subsumed by environmental problems that lead to decreased landings or reduced quality of production. There are indications of a shift from a demersal dominated fish community to a pelagic 
dominated fish community over the last half of the $20^{\text {th }}$ century [6]. The pelagic food web on the Mississippi River influenced shelf has changed in the last several decades to the point where it is now poised to switch between one with, and one largely without, the diatom-zooplankton-fish food web [45]. There are also shifts in diatom community composition with implications for carbon flux [12] and increased jellyfish abundance from 1987 to 1997 [29]. While there have been no catastrophic losses in fishery resources in the northern Gulf of Mexico, the potential impacts of increasing trophic state and worsening oxygen conditions on ecologically and commercially important species and altered ecological processes warrant attention.

\section{Acknowledgements}

Funding for preparation of this manuscript was provided by the U.S. Dept. of Commerce, National Oceanic and Atmospheric Administration, Coastal Ocean Program grants to N.N. Rabalais and R.E. Turner. We thank B. Cole and A. Sapp for maintaining our data in a manner helpful to analysis of long-term trends and for assistance with the preparation of figures.

\section{References}

[1] Bennett E.M., Carpenter S.R. and Caraco N.F. Human impact on erodable phosphorus and eutrophication: a global perspective. BioScience 2001; 51:227-34.

[2] Bierman V.J. Jr., Hinz S.C., Zhu D., Wiseman W. J. Jr., Rabalais N.N. and Turner R.E. A preliminary mass balance model of primary productivity and dissolved oxygen in the Mississippi River Plume/Inner Gulf shelf region. Estuaries 1994; 17:886-99.

[3] Boesch D.F. Challenges and opportunities for science in reducing nutrient over-enrichment of coastal ecosystems. Estuaries 2002; 25:886-900.

[4] Boynton W.R. and Kemp W.M. "Influence of river flow and nutrient loads on selected ecosystem processes. A synthesis of Chesapeake Bay data." In: Estuarine Science: A Synthesis Approach to Research and Practice, Hobbie J.E. ed., Washington, DC: Island Press, 2000.

[5] Caddy J.F. Toward a comparative evaluation of human impacts on fishery ecosystems of enclosed and semi-enclosed seas. Reviews in Fisheries Science 1993; 1:57-95.

[6] Chesney E.J. and Baltz D.M. "The Effects of Hypoxia on the Northern Gulf of Mexico Coastal Ecosystem: A Fisheries Perspective" In: Coastal Hypoxia: Consequences for Living Resources and Ecosystems, Rabalais N.N., Turner R. E. eds., Coastal and Estuarine Studies 58, Washington, DC: American Geophysical Union, 2001.

[7] Childs C.R., Rabalais N.N., Turner R.E. and Proctor L.M. Sediment denitrification in the Gulf of Mexico zone of hypoxia. Mar Ecol-Prog Ser 2002; 240:285-90.

[8] Childs C.R., Rabalais N.N., Turner R.E. and Proctor L.M. Erratum. Mar Ecol-Prog Ser 2003; 247:310.

[9] Dagg M.J. Physical and biological responses to the passage of a winter storm in the coastal and inner shelf waters of the northern Gulf of Mexico. Cont Shelf Res 1988; 8:167-78. 
[10] Diaz R.J. and Rosenberg R. Marine benthic hypoxia: A review of its ecological effects and the behavioural responses of benthic macrofauna. Oceanogr Mar Biol Annual Review $1995 ; 33: 245-303$.

[11] Donner S.D., Coe M.T., Lenters J.D., Twine T.E. and Foley J.A. Modeling the impact of hydrological changes on nitrate transport in the Mississippi River Basin from 1955 to 1994. Global Biochem Cy 2002; 16(3)10.1029/2001GB001396.

[12] Dortch Q., Rabalais N.N., Turner R.E. and Qureshi N.A. "Impacts of changing Si/N ratios and phytoplankton species composition.” In: Coastal Hypoxia: Consequences for Living Resources and Ecosystems, Rabalais N.N., Turner R. E. eds., Coastal and Estuarine Studies 58, Washington, DC: American Geophysical Union, 2001.

[13] Dortch Q., Rabalais N.N., Turner R.E. and Rowe G.T. Respiration rates and hypoxia on the Louisiana shelf. Estuaries 1994; 17:862-72.

[14] Downing J.A. (chair), Baker J.L., Diaz R.J., Prato T., Rabalais N.N. and Zimmerman R.J. Gulf of Mexico Hypoxia: Land-Sea Interactions. Council for Agricultural Science and Technology, Task Force Report No. 134, 1999.

[15] Dunn D.D. Trends in Nutrient Inflows to the Gulf of Mexico from Streams Draining the Conterminous United States 1972 - 1993. U.S. Geological Survey, Water-Resources Investigations Report 96-4113, Prepared in cooperation with the U.S. Environmental Protection Agency, Gulf of Mexico Program, Nutrient Enrichment Issue Committee. Austin, TX: U.S. Geological Survey, 1996.

[16] Eadie B.J., McKee B.A., Lansing M.B., Robbins J.A., Metz S. and Trefry J.H. Records of nutrient-enhanced coastal productivity in sediments from the Louisiana continental shelf. Estuaries 1994; 17:754-65.

[17] Goolsby D.A., Battaglin W.A., Lawrence G.B., Artz R.S., Aulenbach B.T., Hooper R.P., Keeney D.R. and Stensland G. J. Flux and Sources of Nutrients in the MississippiAtchafalaya River Basin, Topic 3 Report for the Integrated Assessment of Hypoxia in the Gulf of Mexico. NOAA Coastal Ocean Program Decision Analysis Series No. 17. Silver Spring, MD: NOAA Coastal Ocean Program, 1999.

[18] Harper D.E. Jr., McKinney L.D., Nance J.M. and Salzer R.R. "Recovery responses of two benthic assemblages following an acute hypoxic event on the Texas continental shelf, northwestern Gulf of Mexico." In: Modern and Ancient Continental Shelf Anoxia, Tyson R.V., Pearson T.H. eds., London: Geol Soc Spec Publ No. 58, 1991.

[19] Helly J.J. and Levin L.A. Global distribution of naturally occurring marine hypoxia on continental margins. Deep-Sea Res Pt I 2004; 51:1159-68.

[20] Howarth R.W., Billen G., Swaney D., Townsend A., Jaworski N., Lajtha K. Downing J.A., Elmgren R., Caraco N., Jordan T., Berendse F., Freney J., Kudeyarov V., Murdoch P. and Zhao-Liang Z. Regional nitrogen budgets and riverine $\mathrm{N} \& \mathrm{P}$ fluxes for the drainages to the North Atlantic Ocean: Natural and human influences. Biogeochemistry 1996; 35:75-139.

[21] Justić D., Rabalais N.N. and Turner R.E. "Riverborne nutrients, hypoxia and coastal ecosystem evolution: Biological responses to long-term changes in nutrient loads carried by the Po and Mississippi Rivers.” In: Changes in Fluxes in Estuaries: Implications from Science to Management, Dyer K.R., Orth R.J. eds., Fredensborg, Denmark: Olsen \& Olsen, 1994.

[22] Justić D., Rabalais N.N. and Turner R.E. Modeling the impacts of decadal changes in riverine nutrient fluxes on coastal eutrophication near the Mississippi River Delta. Ecol Model 2002; 152:33-46. 
[23] Justić D., Turner R.E. and Rabalais N.N. Climatic influences on riverine nitrate flux: Implications for coastal marine eutrophication and hypoxia. Estuaries 2003; 26:1-11.

[24] Kamykowski D. and Zentara S.J. Hypoxia in the world ocean as recorded in the historical data set. Deep-Sea Res 1990; 37:1861-74.

[25] Mallini L.J. Development of kinetic-colorimetric flow analysis techniques for determining dissolved manganese and iron and an assessment of the behavior of dissolved manganese in the far-field plume of the Mississippi River. Masters Thesis, University of Southern Mississippi, 1992.

[26] Meade R.H. ed. Contaminants in the Mississippi River, 1987-92. U.S. Geological Survey Circular 1133. Denver, CO: U.S. Geological Survey, 1995.

[27] Nixon S.W. Coastal marine eutrophication: A definition, social causes, and future concerns. Ophelia 1995; 41:199-219.

[28] Pokryfki L. and Randall R.E. Nearshore hypoxia in the bottom water of the northwestern Gulf of Mexico from 1981 to 1984. Mar Environ Res 1987; 22:75-90.

[29] Purcell J.E., Breitburg D.L., Decker M.B., Graham W.M. and Youngbluth M.J. "Pelagic cnidarians and ctenophores in low dissolved oxygen environments.” In: Coastal Hypoxia: Consequences for Living Resources and Ecosystems, Rabalais N.N., Turner R.E. eds., Coastal and Estuarine Studies 58, Washington, DC: American Geophysical Union, 2001.

[30] Rabalais N.N. An Updated Summary of Status and Trends in Indicators of Nutrient Enrichment in the Gulf of Mexico. Environmental Protection Agency Publ. No. EPA/800R-92-004. Stennis Space Center, MS: Gulf of Mexico Program, Nutrient Enrichment Subcommittee, 1992.

[31] Rabalais N.N., Harper D.E. Jr. and Turner R.E. "Responses of nekton and demersal and benthic fauna to decreasing oxygen concentrations." In: Coastal Hypoxia: Consequences for Living Resources and Ecosystems, Rabalais N.N. and Turner R.E. eds., Coastal and Estuarine Studies 58. Washington, DC: American Geophysical Union, 2001a.

[32] Rabalais N.N., Smith L.E., Harper D.E. Jr. and Justić D. "Effects of Seasonal Hypoxia on Continental Shelf Benthos." In: Coastal Hypoxia: Consequences for Living Resources and Ecosystems, Rabalais N.N. and Turner R.E. eds., Coastal and Estuarine Studies 58. Washington, DC: American Geophysical Union, 2001b.

[33] Rabalais N.N. and Turner R.E. "Hypoxia in the Northern Gulf of Mexico: Description, causes and change." In: Coastal Hypoxia: Consequences for Living Resources and Ecosystems, Rabalais N.N., Turner R.E. eds., Coastal and Estuarine Studies 58, Washington, DC: American Geophysical Union, 2001.

[34] Rabalais N.N., Turner R.E., Dortch Q., Justić D., Bierman V.J. Jr. and Wiseman W.J. Jr. Review. Nutrient-enhanced productivity in the northern Gulf of Mexico: past, present and future. Hydrobiologia 2002b; 475/476:39-63.

[35] Rabalais N.N., Turner R.E., Justić D., Dortch Q. and Wiseman W.J. Jr. Characterization of Hypoxia: Topic 1 Report for the Integrated Assessment of Hypoxia in the Gulf of Mexico. NOAA Coastal Ocean Program Decision Analysis Series No. 15. Silver Spring, MD: NOAA Coastal Ocean Program, 1999.

[36] Rabalais N.N., Turner R.E., Justić D., Dortch Q. and Wiseman W.J. Jr. Nutrient changes in the Mississippi River and system responses on the adjacent continental shelf. Estuaries 1996; 19:386-407.

[37] Rabalais N.N., Turner R.E. and Scavia D. Beyond science into policy: Gulf of Mexico hypoxia and the Mississippi River. BioScience 2002a; 52:129-42. 
[38] Rabalais N.N., Turner R.E., Wiseman W.J. Jr. and Boesch D.F. "A brief summary of hypoxia on the northern Gulf of Mexico continental shelf: 1985-1988." In: Modern and Ancient Continental Shelf Anoxia, Tyson R.V., Pearson T.H. eds., London: Geol Soc Spec Publ No. 58, 1991.

[39] Rabalais N.N., Wiseman W.J. Jr. and Turner R.E. Comparison of continuous records of near-bottom dissolved oxygen from the hypoxia zone of Louisiana. Estuaries 1994; 17:850-61.

[40] Renaud M. Hypoxia in Louisiana coastal waters during 1983: implications for fisheries. Fish B-NOAA 1986; 84:19-26.

[41] Rowe G.T., Cruz Kaegi M.E., Morse J.W., Boland G.S. and Escobar Briones E.G. Sediment community metabolism associated with continental shelf hypoxia, northern Gulf of Mexico. Estuaries 2002; 25:1097-1106.

[42] Scavia D., Rabalais N.N., Turner R.E., Justić D. and Wiseman W.J. Jr. Predicting the response of Gulf of Mexico hypoxia to variations in Mississippi River nitrogen load. Limnol Oceanogr 2003; 48:951-56.

[43] Seitzinger, S.P., Kroeze C., Bouwman A.F., Caraco N., Dentener F. and Styles R.V. Global patterns of dissolved inorganic and particulate nitrogen inputs to coastal systems: recent conditions and future projections. Estuaries 2002; 25:640-55.

[44] Turner R.E. and Allen R.L. Bottom water oxygen concentration in the Mississippi River Delta Bight. Contrib Mar Sci 1982; 25:161-72.

[45] Turner R.E., Qureshi N., Rabalais N.N., Dortch Q., Justić D. and Cope J. Fluctuating silicate:nitrate ratios and coastal plankton food webs. Proceedings of the National Academy of Science, USA 1998; 95:13048-51.

[46] Turner R.E. and Rabalais N. N. Linking landscape and water quality in the Mississippi River basin for 200 years. BioScience 2003; 53:563-72.

[47] Turner R.E. and Rabalais N.N. Changes in Mississippi River water quality this century. Implications for coastal food webs. BioScience 1991; 41:140-48.

[48] Turner R.E. and Rabalais N.N. Coastal eutrophication near the Mississippi river delta. Nature 1994; 368:619-21.

[49] Turner R.E., Rabalais N.N., Swenson E.M., Kasprzak M. and Romaire T. Summer hypoxia in the northern Gulf of Mexico and its prediction from 1978 to 1995. Mar Environ Res 2005; 59:65-77.

[50] Vitousek P.M., Abler J.D., Howarth R.W., Likens G.E., Matson P.A., Schindler D.W., Schlesinger W.H. and Tilman D.G. Human alterations of the global nitrogen cycle: Sources and consequences. Ecol Appl 1997; 7:737-50.

[51] Wiseman W.J. Jr., Rabalais N.N., Turner R.E., Dinnel S.P. and MacNaughton A. Seasonal and interannual variability within the Louisiana Coastal Current: Stratification and hypoxia. J Marine Sys 1997; 12:237-48.

[52] Zimmerman R.J. and Nance J.M. "Effects of hypoxia on the shrimp fishery of Louisiana and Texas." In: Coastal Hypoxia: Consequences for Living Resources and Ecosystems, Rabalais N.N. and Turner R.E. eds., Coastal and Estuarine Studies 58, Washington, DC: American Geophysical Union, 2001. 